(c) ЕУСПб, 2021. ISSN 2310-3817. Vol. 11, No. 1 c. 156-180

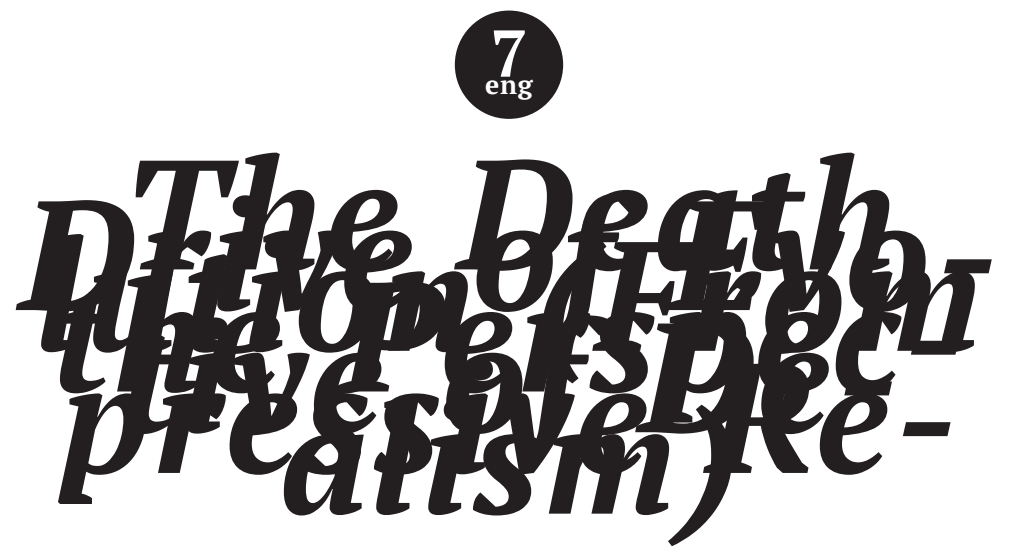

Julie Reshe

Professor, Researcher

School of Advanced Study (SAS), University of Tyumen, Russia, 8 Marta St, 2k1, Tyumen

E-mail: j.reshe@utmn.com

\title{
The Death Drive of Evolution (From the Perspective of Depressive Realism)
}

\begin{abstract}
:
This paper analyses Charles Darwin and Sigmund Freud as depressive realists who attempted to dethrone the human species from their central place in nature and history. Both evolutionary theory and Freudian-Lacanian psychoanalysis partly preserve the idea of human exceptionalism, while considering psychoanalysis's negative conceptualization of humans as the most maladapted species. This maladaption is conventionally conceptualized in psychoanalysis as a rupture from the natural order and is sometimes presented as the embodiment of the death drive. Such a concept of the death drive tends to be seen as an exclusively human drive. Developments in recent evolutionary biology and psychoanalytic thought suggest ways to elaborate on the concept of the death drive as not being exclusively human. Nature's
\end{abstract}


evolution is not the embodiment of progress that results in the appearance of the human species, and it is not the embodiment of a harmony from which humans deviate, but it is rather a rupture with itself. Nature as such is an embodiment of the death drive.

\section{Keywords:}

Depressive realism, death drive, evolution, nature, human exception, Darwin, Gould, Freud, Lacan

Psychologists today are largely in consensus that our perception of reality is unavoidably distorted by positive illusions (Taylor et al. 2000). Human thinking is biased toward positivity and views negative thinking as harmful to our minds and not being compatible with our survival. Be it a reflection on the life of the person, the life of nature, or the life of the universe - they all bear the mark of positive bias. So-called positive illusions of all sorts (such as the illusion of human superiority, i.e., immortality) are necessary to maintain what is considered to be a healthy and thriving psyche. Nonetheless, it is the disillusionment that comes at the cost of anxiety and depression that tends to be associated with the progress of human thought (however, the idea of progress itself could be seen as a consolation and a type of a positive bias).

Evolutionary theory and psychoanalysis could be understood to bear a function of disillusionment. Sigmund Freud put himself on equal footing with Nicholas Copernicus and Charles Darwin in their dethronement of the human species and dealt a great blow to humanity's "naïve self-love.” Freud wrote,

In the course of centuries the naïve self-love of men has had to submit to two major blows at the hands of science. ‘...〉 This is associated in our minds with the name of Copernicus ‘...〉. The second blow fell when biological research destroyed man's supposedly privileged place in creation and proved his descent from the animal kingdom and his ineradicable animal nature. This reevaluation has been accomplished in our own days by Darwin $<. .$. , though not without the most violent contemporary opposition. But human megalomania will have suffered its third and most wounding blow from the psychological research. (Freud 1916-1917: 284-85)

Copernicus's discovery of the earth's rotation around the sun and his denial of the Scripture's scientific authority likely made many 
people depressed (Rifkin 1985: 281). Similarly, the theory of evolution and psychoanalytical insights are often still rejected, partially because they are too painful to bear. Even so, their dethronement of the human species is not the end of the line but is just one step along a never-ending depressive journey. Perhaps the next shift in human thought will be something so depressive that, compared to which, both psychoanalysis and evolution will be considered a consolation.

The psychological conception of depressive realism, which appeared as an opposition to conventional positive psychology, equates depression with the advancement of human thinking. It suggests that facing reality necessarily comes with the disillusionment that causes depression. Paul W. Andrews and Anderson Thomson (2009), adherents of this conception, formulated the hypothesis of analytical rumination. According to this hypothesis, depression can be seen not as a pathological evolutionary formation but as an evolved ability that secures human thinking as such. The symptoms of depressive rumination might be painful, but they are required to sustain the unpleasant thinking process and analysis of complex problems. It should be remarked here that although the hypothesis of analytical rumination supports the concept of depressive realism, at the same time it contradicts its more radical version. In a way it is not depressive enough since the concept bestows depression with a positive adaptational meaning - the evolution and sustenance of the human ability to think. Its message is "It is painful, but it is worth it," whereas more radical depressive realism would rather face the vanity of both depressions and the painful human thinking it sustains.

Disillusioning thinking (or thinking as such) moves in a dialectical process of surrendering to depressive disillusionments and further attempts to escape them; it does not move in a linear fashion toward clarity and revelations, but rather through such internal ruptures, heading toward its own final breakup under the pressure of its internal contradictions (this stage is not normally embodied in books and research papers, since their format demands clarity and does not tolerate contradictions). Such an interpretive framework can be employed in the analysis of both evolutionary and psychoanalytic developments and in analyzing the concept of depressive realism, which contradicts itself in its very formulation (suggesting a more realistic view and the progress of clarification on the expense of depression).

Darwin and Freud might be considered depressive realists, each combining a similar dialectical set of depressive revelations and healing positive biases. We know from Darwin's autobiography, 
health journal, and letters that he suffered from what are now acknowledged to be chronic depression, generalized anxiety disorder, and social anxiety disorder (Darwin 2018). Darwin's symptoms included, among others, fatigue, low self-esteem, hysterical crying, and feelings of imminent death. His depression left him "not able to do anything one day out of three" (Ibid.: 169) and choking on his "bitter mortification" (Ibid.: 148). Darwin particularly struggled with anxiety around presenting and publishing his theory. At the same time, his depression and his various psychological conditions could be a manifestation of him abandoning the positive bias. It might be his experience in sustaining depression that contributed to his ability to disrupt theo-teleological beliefs with his thinking.

Similarly, Freud was also known to suffer from depression. According to his close disciple Ernest Jones, "for many years he suffered from periodic depression and fatigue or apathy, neurotic symptoms, including anxiety attacks ‘... the only respects in which the anxiety got localized were occasional attacks of dread of dying (Todesangst)" (1972: 107, 354). On many occasions, Freud wrote about himself in ways that contradict his own therapeutic indications. Much of his psychoanalytic knowledge derived from his own honest self-analysis, if not the invention of psychoanalysis itself. In his later years, Freud promoted a rather pessimistic view of humans. His theory of the death drive can be conceived as the apogee of his pessimism (McGowan 2013). Freud defines the death drive as "a compulsion to repeat which overrides the pleasure principle" (1990: 24). His later writings tended toward understanding humans as being made up of underlying repeated compulsion and self-destruction. Psychoanalysis under Freud's guidance presented a pessimistic view of human nature, considering it to be a rather unfortunate break from animality without its full erasure. In one conventional psychoanalytic interpretation, the death drive is what designates this break.

No matter how depressive and disillusioning psychoanalysis and the theory of evolution are, they are far from being fully deprived of positive bias. Natural evolution is by default thought of as driven toward the multiplication, preservation, and amplification of life. In the common understanding, natural evolution is associated with a positive tendency of gradual progress, a betterment where all living things become more developed and more adapted to the environment. A permanent and gradual betterment, fewer flaws, more perfection - the species follow an evolutionary destiny breaking the path from reptiles to mammals, from ape-like ancestors to the supreme creatures called humans, everything is clearly moving toward a happy ending. If opposite catastrophic or negative aspects 
of nature are evoked (such as entropy, death, extinction, large-scale mutations, natural disasters, pandemics) or accounted for as a necessary part of the dialectics of nature, they are considered secondary to the central focus on positive processes aimed at life. They are seen as those that the power of life will eventually overcome. Such a positive bias of evolutionary theory is directly inherited from a Judeo-Christian theological perspective. In this context, death and other negative evolutionary aspects are connoted with the more traditional category of evil, while life and positive aspects are connoted with good. To demonstrate the conventional way of thinking that is applied to evolution, Stephen Jay Gould cited Alexander Pope's lines from Essay on Man:

All Nature is but art, unknown to thee;

All chance, direction, which thou canst not see;

All discord, harmony not understood;

All partial evil, universal good.

(Pope, quoted in Gould 1989: 44)

In natural evolution, as in everything else, we tend to search for a deeper (and better) meaning behind the more immediate negative appearances we face. Evil is recognized here only as being partial in relation to the universal good, it is accounted for as something that will be overcome or that is predestined to be suspended by the powers of good - the devil is an integral part of God's bigger plan. The struggle between good and evil is a dialectic that God brought about for the good to prove its victory or superiority over evil. Suffering is a part of the plan God uses to humble us and make us stronger. The devil as God's antagonist is used in God's plan, so he ultimately serves God, with death being presented as an instrument of eternal life. The demonic powers embodied in death and suffering are in the service of a divine plan of salvation to set up the final divine triumph. A similar theological perception is employed in conventionally understood Hegelian dialectical thinking: it implies that at each stage of progress there is a thesis opposed by an antithesis, transcended by an affirmative synthesis, lending itself to the next stage of progress. With his dialectical method, Hegel reconciled destruction and other negative elements by seeing them within a larger pattern, as an engine of progress toward the self-realization of the Spirit.

We employ a similar logic routinely in life, whenever we encounter something that we consider evil or negative, our comforting wishful thinking adds to it a coherency by applying a larger perspective in 
which the evil will be defeated by the power of good-everything is for the best (a similar aim, of bringing narrative coherence, is inherent in the conventional practice of psychoanalysis). Without such a sugar-coating of the cruel realities, life (and thinking) would become unbearable.

Theology is comforting since it presupposes a higher transcendental realm that ensures universal goodness and harmony. It endows nature and human life with goal and meaning - the return to the divine realm. Idyllic transcendental harmony also underlies the principle of hierarchical gradation of living beings in accordance with the extent to which they correspond and reflect the transcendental realm. Humanity in such a perspective is "the crown of creation," since "God created the human in his own image and likeness and for his glory" (Genesis 1:27).

According to Marx's famous passage, evolutionary thinking confronts every aspect of theological and teleological perspectives: "not only is a death blow dealt here for the first time to 'Teleology' in the natural sciences but their rational meaning is empirically explained" (Marx 1942 [1861]). Darwin is presumably considered to reveal that evolution has no purpose and meaning, and no final causes. In line with Marx's reasoning, Daniel Dennett states in his book, Darwin's Dangerous Idea, "I would encounter an idea-Darwin's idea - bearing an unmistakable likeness to universal acid: it eats through just about every traditional concept, and leaves in its wake a revolutionized world-view, with most of the old landmarks still recognizable, but transformed in fundamental ways" (1995: 63). In Dennett's interpretation, Darwin's perspective is opposed to the imposition of "meaning" or "purpose" that define the theological perspective: "It assumes a world that is absurd in the existentialist's sense of the term" (Ibid.: 172). Dennett's interpretation envisioned Darwin as the figure of a depressive realist. However, this interpretation is rather questionable.

Darwin, originally born a Christian and later becoming a student in theology (he matriculated at the University of Cambridge in 1828 with the goal of entering the ministry), gradually changed his views after studying biological and geological facts that turned out not to fit into a theological framework. Even so, according to Robert J. Richards, after he adopted a materialistic view of the world, "Darwin accomplished this revolution, however, not so much by discarding the older framework as by reconstructing from within it" (2009). Although Darwin is generally believed to have eliminated the transcendental realm and to have preserved only natural changes, he nonetheless kept the idea of improvement and progress. Such 
improvement is not of a kind that is imposed from the transcendental realm but was dictated in Darwin's theory by natural necessity: changes in the species occur through random variations, but only those changes that are necessary for adaptation are preserved. Darwin believed that species evolve gradually by undergoing changes that help adaptation. Selection, the main driving force of Darwinian evolution, leads toward organisms' increasing adaptation and more complex adaptive features. He thought of evolution as a gradual accumulation of those advantageous changes and believed that he had proven the principle natura non facit saltum (Latin for "nature does not make leaps"). Darwin's survival of the fittest principle sustained by natural selection is still inscribed into the perspective that suggests a founding harmony and descending gradation. One might conclude that Darwin's adherences were positively biased when concentrating on the beneficial changes that contribute to survival - the side that guarantees the sustenance of natural harmony. According to Richards' conclusion, Darwin simply reconstructed the teleological framework to preserve the superiority of man, which, we might speculate, made Darwin's theory psychologically acceptable to deal with. Richards concludes, "Darwin's theory preserved nature's moral purpose and used teleological means of doing so. Darwinian evolution had the goal of reaching a fixed end, namely man as a moral creature" (Ibid.). The evolutionary emergence of a human moral mind was for Darwin a way to justify the death and destruction caused by natural selection; he claimed that "from the war of nature, from famine and death, the most exalted object which we are capable of conceiving, namely, the production of the higher animals, directly follows" (1859: 490). Darwin considered evolutionary destruction only as a reinforcement of moral meaning and the idea of human superiority.

In fairness to Darwin, he did doubt the idea of betterment. He recognized that his theory of natural selection did not necessarily imply a statement about progress, but only described changes that organisms undergo over time. In one of his letters, written in 1872, Darwin admits, "after long reflection, I cannot avoid the conviction that no innate tendency to progressive development exists" (quoted in Gould 1989: 468). Darwin would also admit that he underestimated the existence of random meaningless changes:

In the earlier editions of my Origin of Species I perhaps attributed too much to the action of natural selection or the survival of the fittest. 〈... I did not formerly consider sufficiently the existence of structures, which, as far as we can at present judge, are neither beneficial 
nor injurious; and this I believe to be one of the greatest oversights as yet detected in my work (...) I was not, however, able to annul the influence of my former belief, then almost universal, that each species had been purposely created; and this led to my tacit assumption that every detail of structure, excepting rudiments, was of some special, though unrecognized, service. Anyone with this assumption in his mind would naturally extend too far the action of natural selection, either during past or present times." (Darwin 1874: 42)

Darwin only partially surrendered to theological comfort by accepting the themes of progress and meaning as a general tendency in life's history (Gould 1989: 258). He never fully resolved this personal inconsistency of the alliance to both contradictory views. As Gould saw it, Darwin could be seen as both a critic and a propagator of progressivism. Darwin's partial surrender to the comfort of the idea of progress became the leitmotif for future evolutionists who came to believe that selection works in favor of better-adapted and superior organisms. Even the relatively recent field of evolutionary developmental theory (evo-devo), according to Lorenzo Chiesa's conclusion, "continues to partake of the old Darwinian finalism of adaptation aimed at an incrementalist evolution of Life" (2018: 47).

\section{II.}

Psychoanalytic theory ventures a step further in combating Darwinistic positive bias by demystifying the theo-teleological, anthropocentric, and vitalist kernel it rests upon. As mentioned, Freud considers psychoanalysis to be an even more wounding blow than Darwin's recognition of human beings as descended from the animal kingdom. Elaborating on Freud, in his first two seminars (1953-1955) Jacques Lacan insists on humans' failure in "natural" adaptation. According to Lacan, there is a constitutive biological discord between human beings and their natural environment. This view of relationships between humans and their environments directly contradicts the Darwinian teleological assumption of a natural consistency and human superiority. For Lacan, the symbolic becomes a second nature or human pseudo-environment that distinguishes humans from other animals. This symbolic pseudo-environment is characterized by "a very particular insistence" (Lacan 1988 [1954-1955]: 61), the compulsion to repeat, which makes it anti-vital and disrupts the idea of life as balance. As Lacan has it in his second seminar, "the dimension discovered by analysis is the opposite of anything which progresses through adaptation, through 
approximation, it is something which proceeds by leaps, in jumps" (Ibid.: 86). Slavoj Žižek summarizes Lacan's perspective on humans as death-driven beings in the following way:

We should bear in mind the basic anti-Darwinian lesson of psychoanalysis repeatedly emphasized by Lacan: man's radical and fundamental dis-adaptation, mal-adaptation, to his environs. At its most radical, "being-human" consists in an "uncoupling" from immersion in one's environs, in following a certain automatism which ignores the demands of adaptation - this is what the "death drive" ultimately amounts to ‘... the "death drive" as a self-sabotaging structure represents (...) a behavior uncoupled from the utilitarian-survivalist attitude. (Žižek 2009: 231)

In Seminar VIII, Lacan continues to insist that the death drive is what evolutionary thinking is unable to comprehend, a "paradox it seems to me quite insoluble in the evolutionary perspective" (1960-1961: 87). He explicitly contrasts the psychoanalytic to the evolutionary perspective because the latter, unlike the former, does not incorporate ruptures. In contrast to the theory of evolution, psychoanalysis makes it possible "to return to these elisions, to show the gaps which the whole theory of evolution leaves open in so far as it always tends to cover up, to facilitate the understandableness of our experience, to reopen these gaps is something which to me seems essential" (Ibid.: 86-87). In this respect, Lacan's main critique is the evolutionary perception of the human as the cumulative result of progress deprived of gaps, as the "flower of consciousness at the end of an evolution" (Ibid.: 86). Lacanian thinkers tend to inherit such an understanding of the death drive as a rupture from the natural order. It is this rupture that supposedly establishes human beings as such.

Following Lacan's legacy, when the theory of evolution is evoked as a target for criticism by psychoanalytic thinkers, it is normally presented with the accent on its positive bias as being continuous and devoid of constitutive gaps, that is, as the process in which stages progressively follow one another and serve the purpose of adaptation, improvement, and other kinds of gradual betterment. Psychoanalytic thinkers rightfully tend to equate the theory of evolution with theology, and on this basis oppose their thinking to it. They would criticize the theory of evolution as ultimately employing a naturalized teleology and establishing the progressive continuity between less developed and more developed species, as well as between humanity and animality (natura non facit saltum). 
Todd McGowan asserts that from the perspective of psychoanalysis the problem with evolution concerns its complete reduction of existence to adaptation: "For psychoanalysis, the untruth of evolution resides in precisely the other direction: it fails to leave a place for the disruptions in the forward movement of life. Far from being undermined by having too many gaps, evolutionary theory presents us with the illusion of an entirely natural history, a history without breaks" (2013: 241). Accordingly, in the evolutionary perspective human consciousness is reduced to natural advancement and fails to be seen as constituted by the rupture in nature. From this, McGowan concludes that the theory of evolution-because of its inability to consider gaps - is not attuned to incorporate the death drive. McGowan, in a similar way to other psychoanalytic thinkers, tends to see this deathlike break as being tied to the emergence of the subject, and therefore as "unnatural." He writes, "subjectivity emerges through a break, through a moment in which death is injected into life and thereby throws life off its course" (Ibid.). Elaborating on Lacan, psychoanalytic thinkers tend to comprehend human beings as a rupture with the continuity of nature, and in this respect, as an embodiment of the death drive. The psychoanalytic concept of the death drive is predominantly conceptualized as an exclusively human phenomenon, as it is reduced to human subjectivity. However, McGowan also suggests that to connect psychoanalytic and evolutionary perspectives, a conception similar to that of the psychoanalytic gap must be included in evolution: "If we can reconcile psychoanalytic thought with evolutionary theory, the latter must incorporate some conception of a break in the flow of life" (Ibid.). He guesses that there must be something disruptive in the evolution itself that allows for this luck, "a fundamental gap in the evolutionary process must have already been there" (Ibid.).

In conventional Lacanian accounts of human nature, a human is a death-driven creature, that is, a corruption or failure to be a proper animal. What constitutes a human is seen as compensation for this lack. Human animals compensate for their missing part, their lack of instincts and natural adaptation, making up for this lack with the establishment of symbolic environment. This view solves the evolutionary problem of direct continuity between animal and human, since what constitutes a human is an irreducible gap between them, a break with nature. But the problem with such a psychoanalytic interpretation is that although it preserves continuity for the rest of nature, it still implies a proper natural animal, an organic creature with no ruptures, adapted and in harmony with nature. It also suggests that there is something in humans themselves that is 
natural, that humans are established upon the rupture from the initially natural, healthy animalistic version of themselves. In humans, instincts (that secure a utilitarian-survivalist attitude) are replaced by drives, they are perverted in contrast to the pre-culture state of animality. With this, one might conclude that Lacan preserves the idea of naturality and teleological evolution with no ruptures for the rest of nature (Zupančič 2017).

Alenka Zupančič (2017) recognizes that in their conventional interpretation, the Freudian-Lacanian move beyond teleology preserves the idea of the exclusivity of humankind. Zupančič maintains that in its conventional interpretation, Lacan's thinking is not deprived of the idea of human exception, which he employs when understanding humans as constituted by rupture from the natural order. The death drive understood as an inherent deviation is what constitutes in Zupančič's view the "(psychoanalytic) carrier of the "human exemption" (Ibid.: 92). This Lacanian, healthy version of an animal is in Zupančič's words, a "complementariness of needs and their satisfaction; whereas the non-existence of such principle is the prerogative of man" (Ibid.: 91).

Even considering a psychoanalytic distinction between adapted animals and dis-adapted death-driven humans, ultimately both animals and humans are seen here as adapted, but the latter are considered as adapted in a special compensatory way, as sick animals forced to creatively compensate for their pathology. Viewed from this psychoanalytic perspective, humans are pathological creatures, but this pathology is also implicitly understood in conventional psychoanalysis as a triumphant adaptation. Human symbolic readaptation, in Chiesa's (2009) summary can be seen as re-naturalization of the maladapted nature of Homo sapiens. Humans are adapted, but in a pathological way, we might say in a way of developing a bad coping mechanism to compensate for the absence of normal animal adaptation. As long as nature is understood as an adaptive process, humans as re-naturalized animals are still seen as partaking in it.

The conventional interpretation of the Freudian-Lacanian account of human maladaptation/readaptation and the death drive as a specifically human-establishing faculty relies on theological presuppositions. Although negatively, it reestablishes human superiority, even though this superiority is negative. Such a psychoanalytic view of human exclusivity is similar to what Russian folk psychology describes with the term koroleva govna (lit. "the queen of shit"). The queen of shit is someone who excessively trash-talks herself and her appearance (such as saying that she is the ugliest and the stupidest person). Through this self-humiliation, she asserts her exclusivity 
and her (negative) superiority; she is the best at being the worst. One might claim that the queen of shit employs a conventionally understood Hegelian dialectical methodology, she negates positive characteristics to establish a positive-negative synthesis and attain the title of "Your Shitty Highness" (which is a great life hack, by the way). This echoes Žižek's evocation of Martin Luther's suggestion of humans' excremental identity. Luther suggests that "man is like divine shit, he fell out of God's anus" (Žižek 2009: 187). Žižek further wonders if "we can, of course, pursue the question of the deep crises that pushed Luther toward his new theology" (Ibid.: 187) - it looks like Russian folk psychology has a diagnosis for this. Such self-abasement and reduction of the human to a miserable excremental entity allows them to sustain their shitty, but nonetheless exceptional status. This mixture of self-contempt and self-deification is what still defines the current trends in both the evolutionary and psychoanalytic inspired self-perceptions of humans. Reflecting on the Darwinian and Freudian blow to humanity's self-love, Adrian Johnston brings up Blaise Pascal's claim: “Man's greatness comes from knowing that he is wretched: a tree does not know it is wretched. Thus it is wretched to know that one is wretched, but there is greatness in knowing one is wretched" (Pascal, quoted in Johnston and Malabou 2013: 83). Pascal's logic suggests paradoxical superiority: humans are superior because they know they are not. By the very dethronement of the human species, conventionally understood psychoanalysis negatively reinscribes them into their special place. In an analogous manner, depressive realism paradoxically supports the realization of human insignificance to become the negative affirmation of human superiority.

\section{III.}

Recent endeavors in both evolutionary theory and psychoanalysis push their intention of anti-humanism and anti-vitalism further, while both are moving through the articulation and eradication of their own theo-theological assumptions. After exposing Lacan for limiting constitutive incompleteness only to humans and rejecting it for other animals and the rest of nature, Zupančič offers another, more radical and contra conventional reading of Lacan. In such a reading, she relies on Žižek's stance of the incomplete constitution of reality from which follows that as reality as such is incomplete, it involves ruptures and fundamental non-coincidence: not only human animal but reality as such is incomplete, deviation is original not only in the case of human beings. The natural norm (for exam- 
ple, biological law) is secondary to nature's incomplete ontological constitution; it is one of its forms. In line with Žižek's ontologically incomplete constitution of reality, Zupančič claims that nature does have laws (in the scientific sense), but its lawfulness (the positive order of nature) is "nothing else but the very structuration (and solution) of its own inner antagonism ('chaos') ‘...〉 the very form of this 'chaos" (2019). Because the inner antagonism is constitutive, no structuration can suspend or overcome it. Nature is chaotic, with no harmony or balance at its core. The harmony and coherent narrative are not merely a product of our wishful imagination, but rather a by-product and a constellation of this chaos. One could add to this line of thought that humanity is not an exception since nature as such is a rupture from itself, a crack within itself, in its own endlessly "sick" pathological version. While it is true that a human is a rupture from nature and from itself, the same can be said to be true for any other living organism, such as a rat or a virus. Just like humans, they are not a result of accumulative adaptations and embodiments of the utilitarian-survivalist pattern, but rather death-driven, permanently mutating contingent structurations of nature. There is no positive natural order of things, no ultimately harmonious nature that fully coincides with itself. It is entirely a maladaptation or deviation (or rupture) from itself, with no positive compensatory result. What we define as a favorable adaptation is a deviation from the previous deviation, where nothing is ever healed. Here no recovery or adaptive processes are possible; the same goes for the human psyche. What is called "health" arises as a deviation to replace the deviation that we call "sickness." Nature exists in its deviated version, for it is a permanently "sick" version of itself. Formations of nature are, rather, deviations from its deviations or a sickness of its sickness, with no positive (dialectizable) outcome into health and harmony. What we call "health" or a "natural balance" are just variants of this "sickness."

Opposing himself to an anthropocentric and vitalist perspective, Chiesa (2009) elaborates a similar reinterpretation of the Lacanian death drive. He suggests that

the animal's death instinct could be seen as compatible with the idea of life as a homeostatic equilibrium insofar as the latter is structurally undermined by entropy. The individual animal as a homeostatic persistence, or conservation of energy, is concomitantly also characterized by a loss or degradation of energy, that is entropy: in this sense, it is always-already "concerned with dying" '...।, it does not seem exaggerated to propose that the human death instinct 
counter-balances entropy, if not actually diminishes "and slows it down, and thus prolongs, or at least complicates, the trajectory of the animal death instinct”. (Ibid.: 108-09)

Žižek substitutes the traditional interpretation of Hegel's dialectical process as evolutionary teleology with his interpretation of Hegel, which does incorporate gaps. By this interpretation, Žižek performs what he claims to be a Freudian intervention in the classical understanding of Hegel's dialectical process. In the traditional reading of Hegel, previous narrative states are negated and progressively sublate their content to a higher level. Žižek asks, "Is the whole point of the dialectical process not that, precisely, we never go through a zero point, that the past content is never radically erased" (2011: 306). What Žižek suggests as a materialist substitute for Hegelian teleology is the dialectics driven by the principle of absolute recoil. For Žižek, the absolute recoil is the heart of his ontological incompleteness of reality. The absolute recoil means an absolute recoil upon itself; it is an immanent gap or discord. This self-referential circle of the absolute recoil goes through a zero point, its ruptures. Therefore, "Hegel's dialectic is the science (...) of accounting for this gap" (2012: 273). Every new form arises as a rupture within the old form. Such a Freudian-Lacanian way of interpreting Hegel is, according to Žižek, the exact opposite of Hegel's teleological narrative in which formations follow successive stages of development. This makes it impossible to describe the rise of the new in terms of a continuous narrative and gradual progress associated with evolution. According to this, Žižek's reading at the core of Hegel's dialectical process is "non-dialectizable" absolute negativity, a repetition that purely repeats itself, which corresponds with Žižek's interpretation of Freud's death drive, "the death drive or the compulsion to repeat lies at the heart of negativity” (Ibid.: 493). Žižek's insists that

the relationship between Hegel's negativity and Freud's death drive (or compulsion to repeat) is thus a very specific one, well beyond their (hidden) outright identity: what Freud was aiming at with his notion of the death drive - more precisely, the key dimension of this notion to which Freud himself was blind, unaware of what he discovered - is the "non-dialectical" core of Hegelian negativity, the pure drive to repeat without any movement of sublation. (Ibid.: 500)

Žižek's interpretation of the death drive sounds appropriate to incorporate into a revised (post)evolutionary theory, but the problem that remains here and there is that for Žižek, this "non-dia- 
lectical" core of negativity is for the most part reduced to the core of the subject, the "threatening excess of negativity of the subject itself” (Ibid.:503). Žižek's Freudian intervention into Hegel seems to overthrow the evolutionary perspective, which implied a continuity between humanity and animality. However, similarly to Hegel and Lacan, Žižek sometimes looks anthropocentric, insofar as the subject and symbolic order are at the center of their attention. The medium of absolute recoil is symbolic, it requires a reflecting human subject. The supreme result of Žižek's “ontological incompleteness of reality" is what gives rise to the subject as its apogee. For Žižek and Lacan, psychoanalytic concepts of rupture, such as that of the death drive, are mostly elaborated with a privileged inference to human consciousness. Even if other incompletenesses of reality are evoked, they are habitually presented as preconditions of a human bearing rupture.

In Sex and the Failed Absolute, Žižek once again argues that what distinguishes human from animal is the domain of the death drive; "this distortion-destabilization of the animal instinctual life" (2019: 326). Žižek depicts Freud's basic lesson as the idea that "there is no 'human animal,' a human being is from its birth (and even before) torn out of the animal constraints, its instincts are 'denaturalized,' caught in the circularity of the (death-)drive, functioning 'beyond the pleasure principle"” (Ibid.: 134). To this he attributes the death drive to a human subject. However, in the same text he suggests "a step further," claiming that

one should even venture that there is no animal tout court, if by "animal" we mean a living being fully fitting its environs: the lesson of Darwinism is that every harmonious balance in the exchange between an organism and its environs is a temporary fragile one, that it can explode at any moment; such a notion of animality as the balance disturbed by the human hubris is a human fantasy. (Ibid.: 326)

In this passage he rejects the previously implied idea of nature as coherent and representing it as incomplete. Žižek's step further detaches the idea of death drive from humans instead capturing it as a structural feature of nature. Here Žižek makes a move from positively biased Darwinism to depressive Darwinism, from a conventional interpretation of Lacan to his radicalized version, from anthropocentric Žižek to a breakup with this version of himself.

To support his logic of ontological incompleteness, Žižek sometimes borrows the concepts of "spandrels" and exaptations. Stephen Jay Gould and Richard Lewontin took the term "spandrel" from 
architecture and applied it to evolutionary biology in their 1979 paper "The Spandrels of San Marco and the Panglossian Paradigm: A Critique of the Adaptationist Programme." This term initially designated the gap at the corner of an arch. These gaps were not utilized until artists started to paint in them. Gould and Lewontin defined a spandrel as a biological characteristic that develops as a by-product some other characteristic's evolution. This term helped them to define evolution as lacking direction, progress, or betterment. Unlike adaptation, spandrels are rather an empty place, something of no use. They have no clear or advance understandable benefit for the organism's survival; however, precisely as such, they may become "ex-apted," that is, acquire a new unexpected function. Gould and Elisabeth Vrba (1982) suggested the term exaptation as a direct replacement for the teleologically loaded term "pre-adaptation." Exaptation points to the principle of multifunctionality and describes a shift in the trait's function during evolution. It designates the process of a trait's retraining form evolving "for" (retrospectively) serving one particular function, but subsequently reoriented to serve other functions. Bird feathers are a standard example of exaptation: previously they performed the function of thermoregulation and only later began to be used for flight.

What Žižek found in Gould is the biological carrier for psychoanalytic concepts of incompleteness and rupture. However, Žižek is mostly interested in Gould's interpretation of the human brain's functions, especially language, as a spandrel. For example, Žižek emphasizes that "the beauty of Gould's idea is that he interprets human language in this way-it's a by-product" (Žižek and Steinbauer 2017). The problem is that this very emphasis on the human brain functions as spandrels remains within the frame of bestowing exclusivity to humans and reduces the concept of spandrels to the analog of the psychoanalytic carrier of human exemption. Gould himself is partially held hostage to this perspective when he discusses spandrels with the goal of finding the biological basis of universal traits in Homo sapiens, he also mentions human contingent "excellence" in this respect, therefore glorifying humans as a shitty crown of creation. On the other hand, Gould's theory in its more radical interpretation suggests precisely the opposite-that evolution as such is based on spandrels. In Gould's view, "a failure to appreciate the central role of spandrels, and the general importance of non-adaptation in the origin of evolutionary novelties, has been the principal impediment in efforts to construct a proper evolutionary theory" (1997). The centrality of spandrels and nonadaptation leads to the conclusion that human brain functions (because they 
are spandrels) make humans a part of nature, rather than humans as an exclusive rupture from nature. More precisely, humans are a rupture from nature but in this they coincide with nature, which is a rupture from itself. Not only has human language and human subjectivity appeared as a rupture but everything else in material reality is equally derived from the form of a rupture. In the context of Gould's extended reasoning, exaptation is what incorporates humans into nature and strips humans of their exceptional status.

\section{IV.}

Gould's revision of Darwin can be rightfully considered as the next step toward a pessimistic revision of evolution, this time pessimistic enough not to remain anthropocentric, although not completely deprived of its positive biases. For Gould (1984), in nature there is no such thing as adaptational continuity. Such continuity is rather a comforting illusion and is a subjective retroactive interpretation that our mind imposes into nature (as it does into the content of our lives), turning it into a coherent positive narrative. In such a perspective, the human species is not the supreme creation of evolution, and the appearance of the human species is not the result of improvement or optimization. Evolution is a different process. Within evolutionary theory, it is commonly implied that the generation of novelties is performed by the gradual optimization of something old. Gould subverts this logic. This subversion can be connoted with the application of the revised (deanthropized) psychoanalytic concept of the death drive. Novelties in the process of evolution are not the gradual improvement of something old but are a by-product of the constitutive destructive force of evolution's structuration. To those who expect to find a coherent narrative in evolution, this force is seen as a rupture. Adapting this view to psychoanalytic discourse, we might say that Gouldian evolution moves through non-dialectizable ruptures that embody its own incoincidence with itself. The material reality exists in the ruins of itself, with nothing existing outside of the ruins. Nature is continuously negating itself, repeating its own destruction.

The Darwinist idea of selection has a teleological residue; it refers to a deliberate act of human beings and implies intentions and goals behind it - the materialistic analogy of hope for spiritual progression toward an immutable order of being. The concept of natural selection as a selection of the fittest was for quite a while critiqued as the "tautology argument." According to this argument, the "survival of the fittest" idea is a meaningless tautology since 
who is the fittest or what is the fitness is defined retroactively by the very fact of survival, which refuses the principle of selection aimed at survival. Those that survive turn out to be the fittest to survive and are retrospectively endowed with the ability to survive. The idea of natural selection can be reduced to the empty tautological statement "Those who survive survive." Even survival and reproduction cannot be seen as a goal of evolution, they are only inscribed to it retroactively. What has survived has survived without any reason for doing so. It is alive and capable of reproducing because it is alive and capable to reproduce. Interestingly, in Lacan's first seminar one can already find similar insight. He claimed that there is no such thing as the struggle for life or the survival of the fittest in nature: "everything tells against this thesis '...'. It is a myth that goes against the facts. Everything goes to prove that there are points of invariability and of equilibria proper to each species, and that species live in a sort of coordinated way" (1988 [1953-1954]:177).

Criticizing the idea of evolution by natural selection, Gould compares evolution with a game of chance (rather than with a tennis tournament, the outcome of which depends upon the players skill). The perception of evolution as a game of chance radically contradicts the teleological perspective that presupposes progress in nature, rather supporting Žižek and Zupančič's interpretation of Lacan's view of nature as constitutively chaotic and disorderly. Speaking, for example, about a game of dice, one would not claim that the whole game was held to confirm the status of its winner (although a conventional common sense can suggest that the winner was destined by fate to win); the status of the winner (the fittest for survival) is defined only by the game's result. The common sense presented in this example is the product of teleological thinking opposed to evolutionary thinking. An even better and more vivid comparison that is royal croquet from Alice in Wonderland, in which the rules change unpredictably. It is unreasonable to believe that the best will win in this game, since it is not known in advance what exactly the player should be better at and how she should show her superiority to win. In his other work, Gould describes the works of evolution, using his memories of visiting a Nairobi recycling market. In this "magical" place, "old telephone wire becomes jewelry, tin cans get sawed in half to be used as kerosene lamps, oil drum tops are beaten into large cooking pans, and treadless automobile tires become sturdy sandals" (1996). Although the tires turn into sandals, no one would argue that tire companies believe that their goal is to provide affordable footwear. The durability of sandals is a latent potential of car tires, the production of such sandals is rather "a quirky 
functional shift" (Ibid.). Nature evolves by using the patterns that already exist in a new way. In psychoanalytic terms, these patterns undergo a point of break from themselves, every new pattern arises as a rupture within the old pattern.

While Darwin tended to believe in evolution as a gradual selection of advantageous changes, Gould opposed the Darwinian leitmotif of gradualism and progress with his theory of punctuated equilibri$\mathrm{um}$. This theory reveals the central role of destructive evolutionary powers. While gradualism suggests that changes occur slowly and consistently, according to Gould's theory, evolution occurs primarily through a variety of ruptures and discontinuities that interrupt periods of evolutionary stasis (Gould 2002a). One example of such a rupture is the mass extinction event, the logic of which is opposite to the logic of betterment and adaptation. Gould warns that one should not underestimate "a mass extinction, with its different rules for survival" (1989: 32); "under the new regulations, the very best of your traits, the source of your previous flourishing, may now be your death knell" (Ibid.: 307). While Darwinians concentrate on positive adaptational changes, here the shift is made to negative tragic changes, which do not bring any possible positive outcome. According to Gould's logic, the moving force of evolution is entropy, a tendency to chaos. Gould's redefinition of evolution as entropic suggests that evolution is not progressive, the narrative of life does not involve increasing adaptability or complexity of life forms (Ibid.: 120). The composition of life on the planet is a "copiously branching bush, continually pruned by the grim reaper of extinction, not a ladder of predictable progress" (Ibid.: 35). Psychoanalytically put, evolution is a death-driven game of ill-adapted losers. Gould openly admits that such a prospect looks to be utterly depressing (Ibid.: 291).

In his defense of psychoanalysis, Chiesa goes as far as to criticize Gould's dialectical Darwinism for his implied vitalism and anthropocentrism connected to his clinging to the very notion of evolution. He asks Gould, "How can there be evolution without progress?" (2018: 47). Chiesa points out that Lacan more radically problematizes the very notion of evolution, “an 'evolution' without progress, like the one Gould implicitly proposes, stands as a thought-provoking oxymoron, but Lacan-informed philosophy should push it further theoretically" (Ibid.: 50). In his Seminar XIX, Lacan does denounce the very notion of evolution, claiming that "there is one thing that is quite certain, which is that it is in the most exaggerated fashion that we put a meaning into it, that the whole idea of evolution, of perfectioning, while in the animal chain that is presupposed, we see absolutely nothing which bears witness all the same to this so 
called continual adaptation" (2018 [1971-1972]: 78). For this reason, according to Lacan, it is necessary to renounce the conception of evolution (as long as it is reduced to selection), since in line with the tautological argument, "it means strictly nothing." With this insight, Lacan suggests that the already depressing notion of evolution is in itself a positive bias against the depression it induces.

\section{V.}

Current knowledge in genomics and microbiology has offered a great shift in the way evolution is understood and does not support the conventional Darwinistic dogma that insists on gradualism, it rather reveals that natura facit saltum

Non-strictly speaking, a gradual evolution to which psychoanalysis conventionally opposes itself is going through a self-suicidal process, bringing it closer to some anti-evolutionary psychoanalytical insight. The chimerism and general mosaic structure of all living organisms, horizontal gene transfer, symbiogenesis, the evolutionary role of viruses, which all were unknown to Darwin, have proved to be not gradual processes, but structurally introducing discontinuities nonreducible to evolutionary continuity (Koonin 2009). Given current knowledge in microbiology, Gould's theory of punctuated equilibrium is considered to be more adequate for describing evolution than Darwinian gradualism. In the spirit of Gould's insights, Darwinian evolutionary theorists are now reproached for not having paid enough attention to the destructive processes that determine evolutionary changes. Moreover, it is suggested that their role might be key to comprehending evolution (Merhe and Raoul 2012). It is now known that random negative choice, the effect of disasters, occurs frequently in microbial populations, "and there is no reason the same types of disasters, less common but just as critical for evolution, have not affected all living things" (Ibid.).

Darwin intentionally ignored catastrophic, discontinuous, and negative aspects in evolution as they did not fit into the framework of his consideration. Darwin's early research concentrated on gradual changes and to a much lesser extent accounted for massive destructive processes. Consequently, the traditional Darwinian perspective on evolution did not take into account the role of discontinuous and destructive forces. Darwinians tend to ignore catastrophic and chaotic events. Such events can drastically reduce population size and may result in genetic drift. No matter how adopted and viable a certain population might seem, no matter how many complex changes it underwent to be qualified as adapted to the environment, the 
catastrophic intervention might abrogate all this. Catastrophe can destroy all, or almost all the population, randomly allowing only a few survivors with their specific genetic features to remain for selection. Those survivors of disaster and their specific genetic constellations do not necessarily have the best set of genes that were accumulated through the selective process of adaptation. Such a negative "selection" process is completely random and is not determined by the level of adaptation of a particular population or organism. "Survival of a disaster may not confer further evolutionary advantages and can in no way be regarded as natural selection of the fittest. Rather, this process is a non-directional selection without an adaptive goal; is merely chance" (Ibid.). Evolution is rather driven by spontaneous destructive changes and catastrophic ruptures of different levels that create a situation when some section of the population or some features of organisms can survive by chance, not by the positive selection that ensure the preference of the fittest ones or the most favorable ones for future adaptation. With such logic, it can be said that different kinds of natural disasters and catastrophes create circumstances and conditions that shape and direct evolution. Evolution "is not unidirectional and does not necessarily favor advantageous mutations to increase fitness; it is rather subject to random selection as a result of catastrophic stochastic processes" (Ibid.).

The destructive power of evolution does not necessarily work through rapid catastrophic intrusions but also through micro-catastrophes, smaller-scale destructive events and slower changes that are incompatible or poorly compatible with survival. Destructive power can also work indirectly by blocking the work of certain processes. Micro-catastrophes may result from internal alterations that are not compatible with survival or from external forces in relation to the organisms like drastic environmental change, to which organisms cannot adjust by employing their set of coping mechanisms. Those are not simply unavoidable but are basic structural process for evolution. Evolution does not aim at life or species preservation, nor on selection of the fittest. It has been estimated that 99.9 percent of all species (over 5 billion) that have ever lived on Earth have died out (Stearns and Stearns 2000), many of whom perished due to cataclysmic events, disasters, or illnesses. There is no hope whatsoever to believe that humanity is not going to become extinct, and if so, similarly to other species it is already and ever was on its way to extinction. The concept of the death drive, when applied to the process of evolution, functions as a proper dethronement of humankind. It implies that humans are not even exclusive in their shittiness, but are just random evolutionary shit, 
and just the same meaningless by-product of destructive and discontinuous forces.

Although Gould's revised evolutionary theory and the direction of recent evolutionary elaborations he inspired might be considered truly, depressingly realistic and therefore strip human existence of any comforting hope; nonetheless, the very manner in which Gould presented his theories does allows space to preserve positive bias. Namely, in his final works Gould (2002b) suggested to see teleological thinking and scientific thinking as a separate realm. In accordance with this suggestion, science and religion are a separate non-overlapping magisteria (NOMA) of human inquiry, while the former deals with the factual processes of the natural world the latter deals with human meanings and purposes. Though theoretically Gould's suggestion is questionable, it might be strategically wise. He was aware that 80-90 percent of Americans have an unshakable belief in the existence of a supreme being. He argued that if one tries to change that, they will not get very far (Gould 2000). The alternative strategy he came up with presents the depressing theory of evolution as existing separately and not threatening the lifesaving comfort of religion. Employing this strategy, Gould has enacted care for both science (guarding it from religion) and for people (guarding religion from science). Gould explicitly argues in favor of NOMA because it allows for a comforting theological space that humans (including Gould himself) are in need of.

Religion is too important to too many people for any dismissal or denigration of the comfort still sought by many folks from theology. I may, for example, privately suspect that papal insistence on divine infusion of the soul represents a sop to our fears, a device for maintaining a belief in human superiority within an evolutionary world offering no privileged position to any creature $\langle. . .>$ I prefer the "cold bath" theory that nature can be truly "cruel" and "indifferent." (Gould 2001: 747)

Teleological thinking is hardwired into us (González Galli and Meinardi 2010), and its bias helps to sustain comforting thinking and reduce the psychological damage that proper evolutionary thinking would cause. This deep-seated bias is a source of misconception toward evolution that posits all change as being for the better, with the life of the universe as an unfolding of some divine plan, with humans believing they are "higher" on accounts that they are more adapted (or "higher" because they are maladapted).

Teleological negativity and tragedy employ an "it's terrible, but...” logic. It allows for the discussion of negativity to ameliorate 
it. It is what Christian theology discloses under the name of the devil, conventional Hegelian dialectics under the concept of negativity, and psychoanalysis under the conventional concept of the death drive - all bitter truths, but the "buts," the "higher" perspectives employed to disclose them (the Divine, the synthesis, the uber-life) are merry, positive biases that help to sustain or escape more horrifying insights. In a word, there is no higher divine or natural force that cares for us, God is an illusion, while the diabolical game he supposedly protects us from, yes, might be the only remaining reality.

One could say that psychoanalytic theory is even more radically depressive than the most depressive version of evolutionary theory. Perhaps it is true that Freud's blow to humanity's naïve self-love is more wounding than Darwin's. While depressive realists (to whom evolutionists and psychoanalysts definitely belong) expose a painful price that we have to pay for knowing, psychoanalytic theory also goes further in subverting the very idea of knowing and to expose the vanity and suspiciousness of any conscious knowledge. Human thinking is not what it considered itself to be, its function is not so much cognition proper but for the most part faking and protection from cognition. To Lacan, anxiety is the most basic affect and the only one that does not deceive (2014 [1962-1963]). It precedes any further rationalizations that comes (in vain) to cover it.

Acknowledgments. The reported study was funded by RFBR and FRLC, project number 20-511-23001.

\section{References}

Andrews, Paul W., and Thomson J. Anderson (2009). "The Bright Side of Being Blue: Depression as an Adaptation for Analyzing Complex Problems." Psychological Review 116.3 (2009): 620-54.

Chiesa, Lorenzo (2009). "The World of Desire: Lacan between evolutionary biology and psychoanalytic theory." Filozofski vestnik [Philosophical journal] 30.2: 83-112.

Chiesa, Lorenzo (2018). “Lacan with Evo-Devo?” In Inheritance in Psychoanalysis, eds. Joel Goldbach and James A. Godley, 44-57. New York: SUNY Press.

Darwin, Charles (1859). On the Origin of Species by Means of Natural Selection, or, The Preservation of Favoured Races in the Struggle for Life. London: J. Murray.

Darwin, Charles (1874). The Descent of Man and Selection in Relation to Sex. London: J. Murray.

Darwin, Charles (2018). Evolution: Selected Letters of Charles Darwin, 1860-1870. Ed. Francis Darwin. New York: Dover.

Dennett, Daniel (1995). Darwin's Dangerous Idea: Evolution and the Meanings of Life. London: Penguin.

Freud, Sigmund (1990). Beyond the Pleasure Principle. New York: Norton.

Freud, Sigmund (1916-1917). Introductory Lectures on Psycho-Analysis. Vol. 15. Ed. James Strachey. London: Hogarth Press. 


\section{Nature and Philosophy}

González Galli L., and Elsa Meinardi (2010). “The Role of Teleological Thinking in Learning the Darwinian Model of Evolution.” Evol Educ Outreach 4.1: 145-52.

Gould, Stephen Jay, Lewontin Richard (1979). "The Spandrels of San Marco and the Panglossian Paradigm: A Critique of the Adaptationist Programme.” Proceedings of the Royal Society of London 205: 581-98.

Gould, Stephen Jay (1984). Darwin et les Grandes Énigmes de la vie. Paris: Seuil.

Gould Stephen Jay, Vrba Elisabeth S. (1982). "Exaptation-A Missing Term in the Science of Form.” Paleobiology 8: 4-15.

Gould, Stephen Jay (1989). Wonderful Life: The Burgess Shale and the Nature of History. New York: Norton.

Gould, Stephen Jay (1996). “Creating the Creators.” Discover Magazine. https://www. discovermagazine.com/planet-earth/creating-the-creators.

Gould, Stephen Jay (1997). "The Exaptive Excellence of Spandrels as a Term and Prototype.” PNAS 94 (1997): 10750-55.

Gould, Stephen Jay (2000). "Evolution and the $21^{\text {st }}$ Century." Annual Meeting of the American Institute of Biological Sciences. https://youtu.be/DRB19MYxaUs.

Gould, Stephen Jay (2001). "Nonoverlapping Magisteria." In Intelligent Design, Creationism and its Critics. Philosophical, Theological, and Scientific perspectives, ed. Robert T. Pennock, 737-49. Cambridge: MIT Press.

Gould, Stephen Jay (2002a). The Structure of Evolutionary Theory. Cambridge, MA: Belknap Press of Harvard University Press.

Gould, Stephen Jay (2002b). Rocks of Ages: Science and Religion in the Fullness of Life. New York: Ballantine Books.

Johnston, Adrian, and Catherine Malabou. (2013). Self and Emotional Life: Philosophy, Psychoanalysis, and Neuroscience. New York: Columbia University Press.

Jones, Ernest (1972). Sigmund Freud Life and Work, Vol. One: The Young Freud 18561900. London: The Hogarth Press.

Lacan, Jacques (2014). The Seminar of Jacques Lacan: Book X. Anxiety [1962-1963]. Cambridge: Polity Press.

Lacan, Jacques (2018). The Seminar of Jacques Lacan, Book XIX: ... or Worse [19711972]. Cambridge: Polity Press.

Lacan, Jacques (1988). The Seminar of Jacques Lacan, Book I: Freud's Papers on Technique [1953-1954]. New York: Norton.

Lacan, Jacques (1988). The Seminar of Jacques Lacan: Book II. The Ego in Freud's Theory and in the Technique of Psychoanalysis [1954-1955]. New York: Norton.

Lacan, Jacques (2002). The Seminar of Jacques Lacan, Book VIII: The Transference [1960-1961]. London: Karnac Books.

Marcaggi, Geoffrey, and Fabian Guénolé (2018). "Freudarwin: Evolutionary thinking as a root of psychoanalysis.” Frontiers in Psychology 9, article 892: 1-9.

Marx, Karl (1942). “Letter to Lassalle” [1861]. Marxists Internet Archive. https://www. marxists.org/archive/marx/works/1861/letters/61_01_16-abs.htm.

McGowan, Todd (2013). Enjoying What we Don't Have: The Political Project of Psychoanalysis. Lincoln: University of Nebraska Press.

Merhej, V. and D. Raoult (2012). "Rhizome of Life, Catastrophes, Sequence Exchanges, Gene Creations, and Giant Viruses: How Microbial Genomics Challenges Darwin.” Frontiers in Cellular and Infection Microbiology 2, article 113: 1-17.

Koonin, E. V. (2009). “Towards a Postmodern Synthesis of Evolutionary Biology.” Cell Cycle 8(6): 799-800.

Merhej, Vicky, Raoult Didier (2009). “Darwin's Place in the History of Thought: A Reevaluation.” PNAS 106: 10056-10060.

Rifkin, Jeremy. (1985). Declaration of a Heretic. London: Routledge and Keegan Paul. Richards, Robert (2009). "Darwin's Place in the History of Thought: A Reevaluation" PNAS 106:10056-10060.

Stearns, Beverly Peterson, and Stephen C. Stearns (2000). Watching, from the Edge of 
Extinction. New Haven, CT: Yale University Press.

Taylor, Shelley E., Margaret E. Kemeny, Geoffrey M. Reed, Julienne E. Bower, and

Tara L. Gruenewald (2000). "Psychological Resources, Positive Illusions, and Health.” American Psychologist 55.1: 99-109.

Zupančič, Alenka (2017). What is Sex? Cambridge, MA: MIT Press.

Zupančič, Alenka (2019). “Human Animal.” NLO 158.4

Žižek, Slavoj (2019) Sex and the Failed Absolute. London: Bloomsbury Academic.

Žižek, Slavoj (2009). The Parallax View. Cambridge, MA: MIT Press.

Žižek, Slavoj (2011) Living in the End Times. London: Verso.

Žižek, Slavoj (2012). Less Than Nothing: Hegel and the Shadow of Dialectical Materialism. London: Verso.

Žižek Slavoj, and Anja Steinbauer (2017) “Interview. Slavoj Žižek” Philosophy Now 122 https://philosophynow.org/issues/122/Slavoj_Zizek. 